\title{
Spatial evolution of Zagros collision zone in Kurdistan, NW Iran: constraints on Arabia-Eurasia oblique convergence
}

\author{
Shahriar Sadeghi and Ali Yassaghi \\ Department of Geology, Tarbiat Modares University, Tehran, Iran \\ Correspondence to: Ali Yassaghi (yassaghi@modares.ac.ir)
}

Received: 1 August 2015 - Published in Solid Earth Discuss.: 22 September 2015

Revised: 22 March 2016 - Accepted: 29 March 2016 - Published: 25 April 2016

\begin{abstract}
Stratigraphy, detailed structural mapping and a crustal-scale cross section across the NW Zagros collision zone provide constraints on the spatial evolution of oblique convergence of the Arabian and Eurasian plates since the Late Cretaceous. The Zagros collision zone in NW Iran consists of the internal Sanandaj-Sirjan, Gaveh Rud and Ophiolite zones and the external Bisotoun, Radiolarite and High Zagros zones. The Main Zagros Thrust is the major structure of the Zagros suture zone. Two stages of oblique deformation are recognized in the external part of the NW Zagros in Iran. In the early stage, coexisting dextral strike-slip and reverse dominated domains in the Radiolarite zone developed in response to deformation partitioning due to oblique convergence. Dextral-reverse faults in the Bisotoun zone are also compatible with oblique convergence. In the late stage, deformation partitioning occurred during southeastward propagation of the Zagros orogeny towards its foreland resulting in synchronous development of orogen-parallel strikeslip and thrust faults. It is proposed that the first stage was related to Late Cretaceous oblique obduction, while the second stage resulted from Cenozoic collision. The Cenozoic orogen-parallel strike-slip component of Zagros oblique convergence is not confined to the Zagros suture zone (Main Recent Fault) but also occurred in the external part (MarekhilRavansar fault system). Thus, it is proposed that oblique convergence of Arabian and Eurasian plates in Zagros collision zone initiated with oblique obduction in the Late Cretaceous followed by oblique collision in the late Tertiary, consistent with global plate reconstructions.
\end{abstract}

\section{Introduction}

As an active orogeny, the Zagros Mountains are evolving through the convergence of the Arabian and Eurasian plates (Fig. 1). The Zagros collision zone in the NW of Iran comprises the internal Sanandaj-Sirjan, Gaveh Rud and Ophiolite zones, and the external Bisotoun, Radiolarite and High Zagros zones (Fig. 1). Zagros orogeny started with obduction of Neotethys oceanic crust upon the Arabian Plate in the Late Cretaceous (Gidon et al., 1974; Kazmin et al., 1986; Karim et al., 2011) followed by early Miocene continent-continent collision of the Arabian Plate with central Iran (Mouthereau et al., 2007, 2012; Allen and Armstrong, 2008; McQuarrie and van Hinsbergen, 2013). Late Cretaceous obduction caused deformation at the northeastern margin of the Arabian Plate, the Neotethys passive margin, (i.e., the Bisotoun and Radiolarite zones) (Gidon et al., 1974; Kazmin et al., 1986; Agard et al., 2005), while Cenozoic collision caused southwestward propagation of Zagros orogeny towards its external Folded Belt zone (Falcon, 1974; Berberian, 1995; Hessami et al., 2001).

GPS measurements show that present Arabian Plate movement is oblique towards central Iran (Vernant et al., 2004). Transpressional zones and strike-slip faults in the Zagros are likely manifestations of the oblique convergence, but their spatial and temporal evolution and their distribution across it remains controversial. It is generally believed that the major belt parallel faults (e.g., Main Recent Fault, MRF) and transverse faults (Kazerun, Karebas, Sabzpoushan and Sarvestan faults) accommodate almost the entire strike-slip component of the Zagros orogeny during Cenozoic continentcontinent collision (Berberian, 1995; Talebian and Jackson, 2002; Allen et al., 2004; Authemayou et al., 2006; Hatzfeld and Molnar, 2010). Similarly, ductile transpression was also 


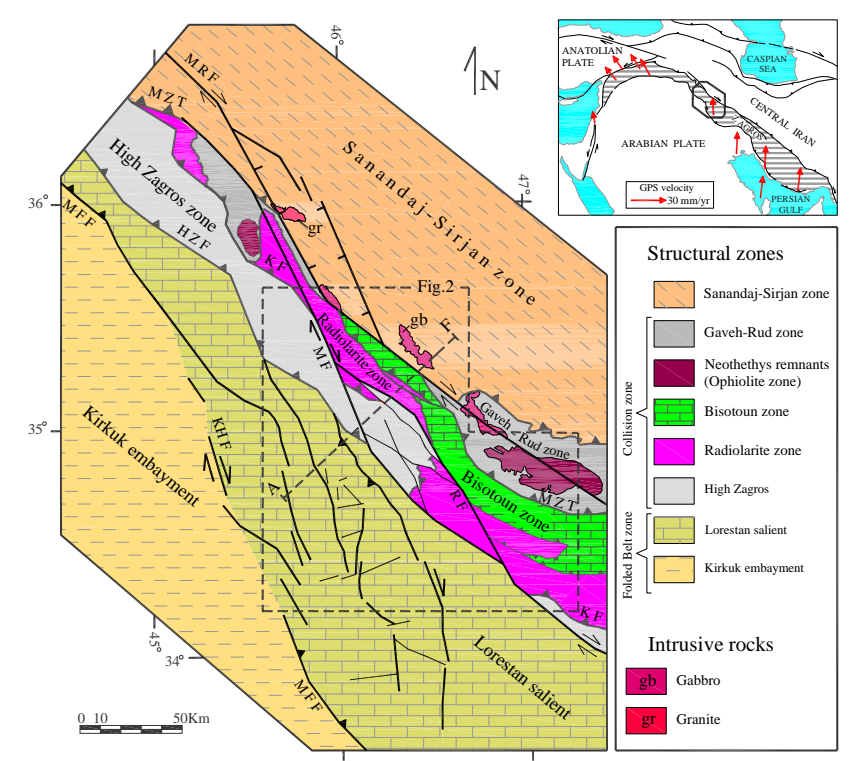

Figure 1. Zagros orogen in NW Iran and NE Iraq (Kurdistan area). Abbreviations: HZF - High Zagros Fault; KF - Kermanshah Fault; KHF - Khaneqin Fault; MF - Marekhil Fault; MFF - Mountain Front Fault; MZT - Main Zagros Thrust. Line A-F is the location of the regional cross section presented in Fig. 6. The inset shows location of the studied area on the geodynamic map of the Zagros. Arrows indicate GPS velocities from McClusky et al. (2000) and Vernant et al. (2004).

proposed for the evolution of the internal part of the Zagros (Sanandaj-Sirjan zone) (Mohajjel and Fergusson, 2000; Mohajjel et al., 2003; Sarkarinejad, 2007; Sarkarinejad and Azizi, 2008). However, structural data that constrain evolution of the Zagros collision zone by oblique convergence since the Late Cretaceous are sparse.

In this paper, stratigraphy, detailed structural mapping and a regional geological cross section are used to constrain the spatial evolution of the Zagros oblique convergence. This study in particular focuses on the external Bisotoun, Radiolarite and High Zagros zones (Fig. 1) in the Iranian Kurdistan area of the Zagros collision zone. Structural constraints on the oblique convergence of the Zagros collision zone in the Cenozoic during its southwestward propagation followed by development of transverse strike-slip faults are also discussed.

\section{Tectonic setting}

The Zagros orogen comprises the internal Sanandaj-Sirjan zone and the external Zagros Fold-Thrust Belt, separated by the Main Zagros Thrust (Falcon, 1974; Berberian, 1995; Mohajjel and Fergusson, 2000; Agard et al., 2005). In the Iranian Kurdistan area, the Zagros orogen is composed of seven zones as the Sanandaj-Sirjan, Gaveh Rud, Ophiolite, Bisotoun, Radiolarite, High Zagros and Folded Belt zones
(Fig. 1). These zones are inherited from Permian-Triassic extensional events related to the opening of Neotethys and Late Cretaceous to Cenozoic compressional events. The Main $\mathrm{Za}-$ gros Thrust (MZT), which separates the Ophiolites, Gaveh Rud and Sanandaj-Sirjan zones from the Bisotoun, Radiolarite and High Zagros zones, is considered here as the Zagros suture zone, though it is proposed as one of the suture zone faults toward the SE (Nemati and Yassaghi, 2010). In this study we use the term Zagros collision zone for the Sanandaj-Sirjan zone, Gaveh Rud volcanic arc, Ophiolite, Bisotoun platform, Radiolarite and High Zagros zones (Fig. 1).

Ophiolite, Gaveh Rud and Sanandaj-Sirjan zones are the internal part of the Zagros orogen emplaced at the margin of the Arabian Plate during closure of the Neotethys Ocean. The ophiolite zone is the remnant of Neotethyan oceanic crust obducted over the Arabian Platform in the Late Cretaceous to early Paleocene (Kazmin, 1986; Agard et al., 2011; Karim et al., 2011). The Gaveh Rud zone comprises volcanosedimentary units more likely formed as the forearc basin of the Sanandaj-Sirjan Arc (Homke et al., 2010) or intraoceanic island arc within the intervening Neotethys Ocean (Ali et al., 2013). It collided with the margin of the Arabian Plate in the Oligocene-early Miocene (23-16 Ma) (Homke et al., 2010; Vergés et al., 2011; Ali et al., 2013). In Iraq, the Gaveh Rud zone is named as the Walash and Naopurdan groups (Ali et al., 2013). The Sanandaj-Sirjan zone has long-lived deformation and magmatism related to Mesozoic subduction (Mohajjel et al., 2003; Azizi and Jahangiri, 2008) and the early Miocene collision (Berberian, 1995; McQuarrie and van Hinsbergen, 2013).

The High Zagros and Folded Belt zones (including the Lorestan salient and Kirkuk Embayment in Fig. 1) evolved on the Zagros passive continental margin. They comprise Permian-Triassic to Cenozoic, thick shelf deposits with some facies changes and discontinuities (James and Wynd, 1965; Koop and Stoneley, 1982; Harrison et al., 1984; Beydoun, 1991). The major differences between the Lorestan Salient and the Dezful Embayment arise from differences in the basal décollement rheology (viscous in the Lorestan vs. frictional in the Dezful Embayment) during deformation as well as absence of the middle décollements (e.g., Dashtak Formation) in the southern part of the Dezful Embayment (Sherkati et al., 2006; Farzipour-Saein et al., 2009, 2014).

The Bisotoun and Radiolarite zones resulted from thinning of the Arabian Plate during Neotethys opening in PermianTriassic time (Searle and Graham, 1982; Kazmin et al., 1986; Fontaine et al., 1989). The Bisotoun zone (or Bisotoun platform) is composed of thick carbonate deposits at the northeastern rim of the Arabian Plate. The Radiolarite zone is 50 to $70 \mathrm{~km}$ wide and developed as a marginal basin (Radiolarite basin) between the Bisotoun platform and the rest of the Arabian Platform (i.e., High Zagros and Folded Belt zones) (Ricou et al., 1977; Wrobel-Daveau et al., 2010; Vergés et al., 2011) (Figs. 1 and 2). 


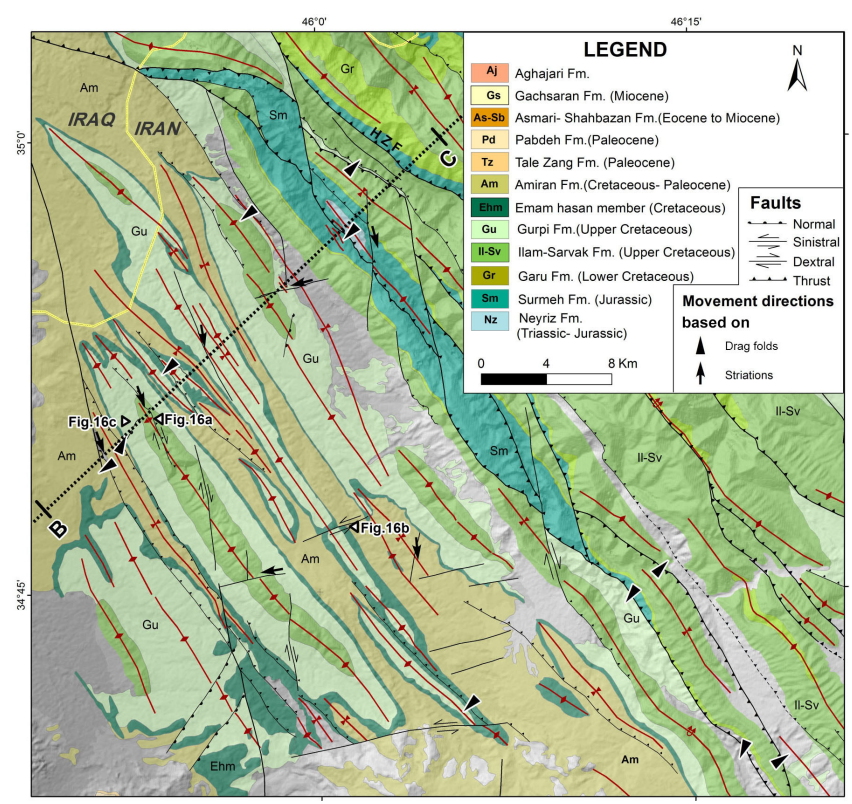

Figure 2. Geological map of the Zagros collision zone in the Kurdistan area (NW Iran). Rectangles show the location of the Kermanshah-Sulaimani area (Fig. 7) and Salas area (Fig. 15). The dotted line (A to $F$ ) is the trace of the regional cross section shown in Fig. 6. For the location of the area within the Zagros collision zone as well as the fault names, refer to captions of Fig. 1.

\section{Tectonostratigraphy of the Zagros collision zone}

Stratigraphic columns of sedimentary basins in the Kurdistan area of the Zagros collision zone (Bisotoun platform, Radiolarite basin, High Zagros zone and Lorestan salient) are shown in Fig. 3. The main tectonostratigraphic events are detailed below.

- From Triassic to Jurassic the Radiolarite basin existed at the northeast margin of the Arabian Platform separated by the Bisotoun platform from the Neotethys Ocean. Carbonate rocks and shales were deposited in both Bisotoun (Braud, 1987) and Arabian platforms (James and Wynd, 1965; Koop and Stoneley, 1982; Sherkati et al., 2006). The Radiolarite basin is filled by up to $300 \mathrm{~m}$ of rhythmically thin-bedded cherts alternating with millimeter-thick shale (Gharib and De Wever, 2010) (Fig. 3).

- During the Early Cretaceous, the thickness of the Garau Formation pelagic sediments increased from $200 \mathrm{~m}$ in the Folded Belt zone to about $1200 \mathrm{~m}$ in the High Zagros zone. This variation is likely related to normal slip along the High Zagros Fault (HZF) and other normal faults in the High Zagros zone. At the same time, in the Radiolarite basin, thick sediments (up to $1200 \mathrm{~m}$ ) consist of radiolarian cherts with slivers of limestone, and brecciated limestones/turbidites were deposited (unit Ra-Li in Fig. 3). These variations reflect simultaneous subsidence of both the High Zagros and Radiolarite basins in the hanging wall of the HZF.

- In the Cenomanian-Turonian, subsidence in the Radiolarite basin and High Zagros decreased, which resulted in sedimentation of the carbonate Ilam-Sarvak formations over the High Zagros and Folded Belt zones. At the same time, the Radiolarite basin filled with thick conglomerates (unit C in Fig. 3) (500 to $1400 \mathrm{~m}$ of pebble and small boulders of limestone and brecciated limestone) (Jassim and Buday, 2006).

The sedimentary basins across the northeastern margin of the Arabian Plate were active until the Late Cretaceous (Fig. 4). Obduction of the Neotethys oceanic crust in the Late Cretaceous-Paleocene is recorded in the stratigraphic column of the Zagros Folded Belt zone by deposition of the Amiran Formation (i.e., Amiran flysh) (Fig. 3). Besides unconformities in the Radiolarite zone (Karim et al., 2011), this tectonic event also caused unconformities in Campanian and Maastrichtian sedimentary cover of the High Zagros zone (Karim et al., 2011). Similarly, development of the growth strata in Campanian-Maastrichtian limestone of the Gurpi Formation in the High Zagros zone (Fig. 5) is also considered to be the result of this tectonic event.

\section{Structure of the Zagros collision zone}

In this section, detailed structural mapping, together with a regional cross section using field and available stratigraphic data, is presented for the Kermanshah-Sulaimani (KS) and Salas areas of the Kurdistan region in NW Iran.

The KS area is a long sector parallel to the main trend of the Zagros (Figs. 2 and 7). The area covers the Bisotoun, Radiolarite and High Zagros zones. The MZT, HZF, Kermanshah Fault (KF) and MRF are major well-known faults within this area. The Marekhil Fault (MF), Paveh Fault (PvF) and Ravansar Fault (RF) are mapped in this study (Fig. 7).

The Salas is located in the western part of the Lorestan Salient (Posht-e-Kuh arc) near to the Kirkuk Embayment of the Zagros Folded Belt zone (Figs. 2 and 15).

\subsection{Regional geological cross section}

A regional geological cross section across the Zagros collision zone in NW Iran (Fig. 6) is drawn using direct field measurements, present stratigraphic data, as well as assumptions about stratigraphy, time and style of deformation as follows.

- The Phanerozoic sedimentary succession of the Zagros comprises 7-12 km (Alavi, 2004) or up to $12 \mathrm{~km}$ (Colman-Sadd, 1978; Falcon, 1974; James and Wynd, 1965; Stocklin, 1968) of sediments including Paleozoic, Mesozoic and Cenozoic strata. We considered the thick- 


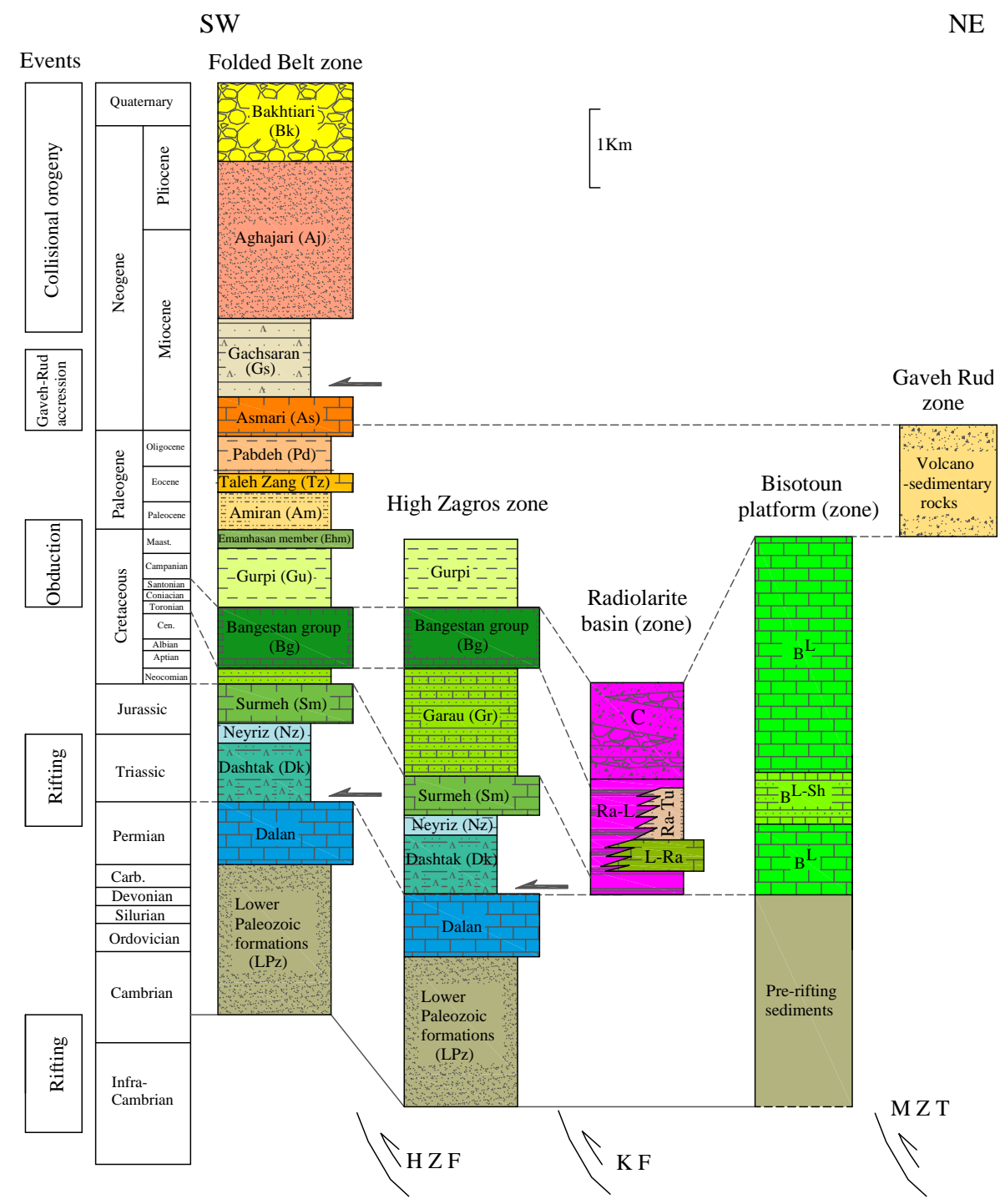

Figure 3. Stratigraphic column of the Zagros collision zones in NW Iran (Kurdistan area). For description of rock units of the Bisotoun platform and Radiolarite basin refer to Fig. 9. Abbreviations: HZF - High Zagros Fault; KF - Kermanshah Fault; MZT - Main Zagros Thrust. This stratigraphic column was prepared using present stratigraphic columns (e.g., Farzipour-Saein et al., 2009; Motiei, 1993) and Radiolarite basin in Iran (Gharib and De Wever, 2010) and Iraq (Jassim and Buday, 2006), as well as field measurements during this study (A to $\mathrm{F}$ line of cross section in Fig. 2).

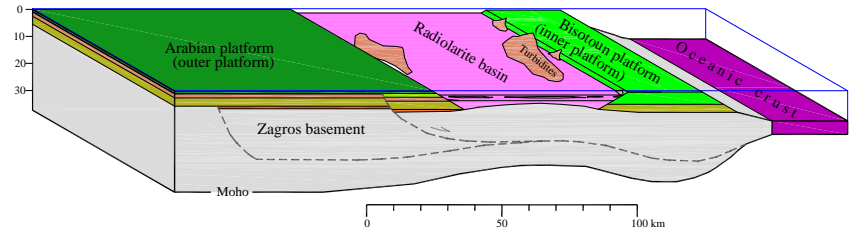

Figure 4. Sedimentary basins across the northeastern margin of the Arabian Plate in the Turonian (Late Cretaceous), just before the obduction of the oceanic crust. ness of about $12 \mathrm{~km}$ (Fig. 3) for this succession in construction of the cross section (Fig. 6).

- Deformation in the Bisotoun (platform) and Radiolarite (basin) zones occurred as thin-skinned tectonics during the Late Cretaceous (Kazmin et al., 1986). Thickskinned tectonics, thus, did not have any major effect on the overall deformation of these zones.

- After collision of the Arabian Plate with central Iran, a thick viscous layer at the base of the sedimentary cover (i.e., Hormoz salt) (McQuarrie, 2004) or its equivalents (Sherkati and Letouzey, 2004) formed a basal décollement zone decoupling basement from the cover during 


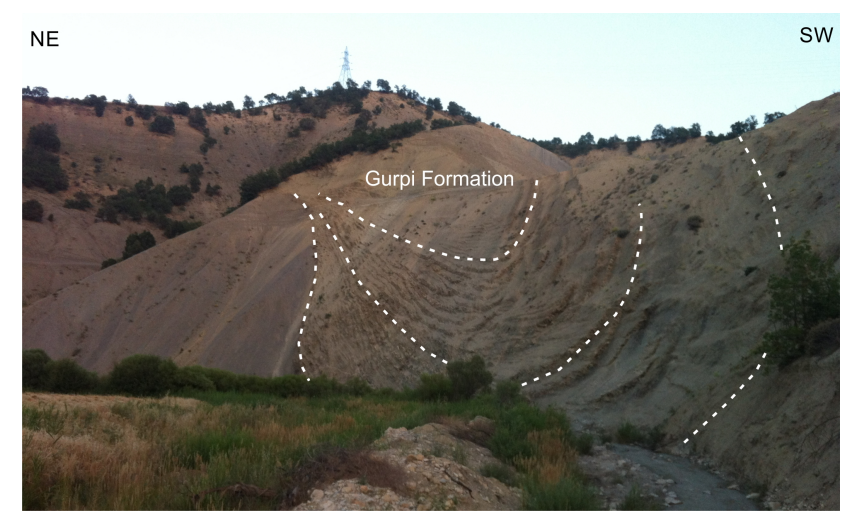

Figure 5. Growth syncline in the limestones of the Gurpi Formation (Campanian-Maastrichtian in age) in the High Zagros zone (see Fig. 2 for the location).

the deformation. The Mountain Front Fault is considered as the SE boundary of the Hormoz salt or its equivalent shale units (McQuarrie, 2004) (Fig. 6).

- The timing of basement deformation is still under debate, but is commonly assumed to occur in the late Cenozoic (e.g., Molinaro et al., 2005; Casciello et al., 2009; Mouthereau et al., 2007).

Restoration of the cross section has been carried out using the line-length balancing technique for all formations except for the Hormoz salt and Radiolarite zone sediments in which the area-balancing technique was applied (Fig. 6b). For the Hormoz salt and Radiolarite zone, 1.5 and $2.5 \mathrm{~km}$ of thickness are assumed, respectively. The area of the Radiolarite zone is estimated based on its surface exposure (breadth) and depth of basement under the Radiolarite zone.

The total shortening of $62 \mathrm{~km}$ is measured for the Zagros external parts (distance between L3 in Fig. 6a and L'3 in Fig. $6 \mathrm{~b}$ ). The $13 \mathrm{~km}$ of this shortening is estimated for the sedimentary cover of both the High Zagros and Folded Belt zones where line-length balancing is applied. The remaining $49 \mathrm{~km}$ of shortening is estimated for the Bisotoun and Radiolarite zones using area balancing (distance between L2 and L'2 in Fig. 6b).

\subsection{Structure of the Kermanshah-Sulaimani (KS) area}

\subsubsection{Early structures}

\section{Fault zones}

The High Zagros Fault (HZF) and Kermanshah Fault (KF) are major reverse faults in the KS area. The HZF is the southwestern boundary of the High Zagros zone, and it controlled basin subsidence of the Garau Formation during the Early Cretaceous (refer to Sect. 3). In the KS area, the HZF zone is well exposed and is about $300 \mathrm{~m}$ in width in which several fault planes and associated asymmetric folds are mapped
(Figs. 7 and 8). These asymmetric folds plunging towards the southeast (Fig. 8b) are developed by oblique faulting with a notable strike-slip component (note the rake angle of about $50 \mathrm{NW}$ in Fig. 8b). The Kermanshah Fault, the other major fault of the KS area, emplaces the Radiolarite rocks over the Arabian Platform (Figs. 1 and 2).

In addition, early faults are also mapped in the Radiolarite and Bisotoun zones (Fig. 9a). Using asymmetric geometry of folds as kinematic indicators (e.g., Doblas, 1998), these early faults in the Bisotoun zone and the NE margin of the Radiolarite zone have dextral-reverse kinematics (Fig. 9a), while in the central and SW parts of the Radiolarite zone they have both dextral-reverse and reverse kinematics (Fig. 9a).

\section{Folds}

In the Radiolarite zone, spectacular map-scale folds are recognized in the field within alternating thick-bedded radiolarite, pelagic limestone and shale strata (Figs. 9b and 10).

According to classification of Fleuty (1964), these folds are classified into three main classes as reclined, plunging inclined and horizontal inclined folds. Using criteria by Jones et al. (2004), these folds' geometries are referred to different kinematic and shear strain scenarios (Fig. 11). Reclined and plunging inclined folds are referred to here as dextral strike-slip dominated domains (Figs. 9b, 10, 11a, b and 12a, b), whereas horizontal inclined folds are mapped in reverse dominated domains (Figs. 9b, 10, 11c and 12c respectively). In narrow bands within both domains, reclined and plunging inclined folds (in dextral strike-slip domain) and horizontal inclined folds (in reverse domains) are more abundant (Fig. 9b).

\subsubsection{Late structures}

The NW-trending Marekhil and Ravansar faults are two main strike-slip faults in the KS area, striking subparallel to the main trend of the Zagros (Figs. 7 and 14d). These faults formed an en echelon array, named hereafter as the Marekhil-Ravansar fault system.

The Marekhil Fault (MF) offsets the early structures such as the Marekhil Anticline (MA in Fig. 13) and the Kermanshah Reverse Fault with a dextral offset of ca. $32 \mathrm{~km}$ (KF in Fig. 13). The southeast sector of the MF overprint the HZF (Fig. 7). Similarly, the Ravansar Fault (RF in Fig. 7) also offsets the KF (Fig. 7).

In some faults, two sets of fault striations are observed that are interpreted as the early reverse (S1 in Fig. 14) and the late strike-slip kinematics (S2 in Fig. 14).

\subsection{Structure of the Salas area}

Geometry and kinematic analysis of faults and related folds in the Salas area (Fig. 15) showed that similar to the other regions in the Zagros Folded Belt zone, the main fault systems are thrusts (e.g., Berberian, 1995; McQuarrie et al., 

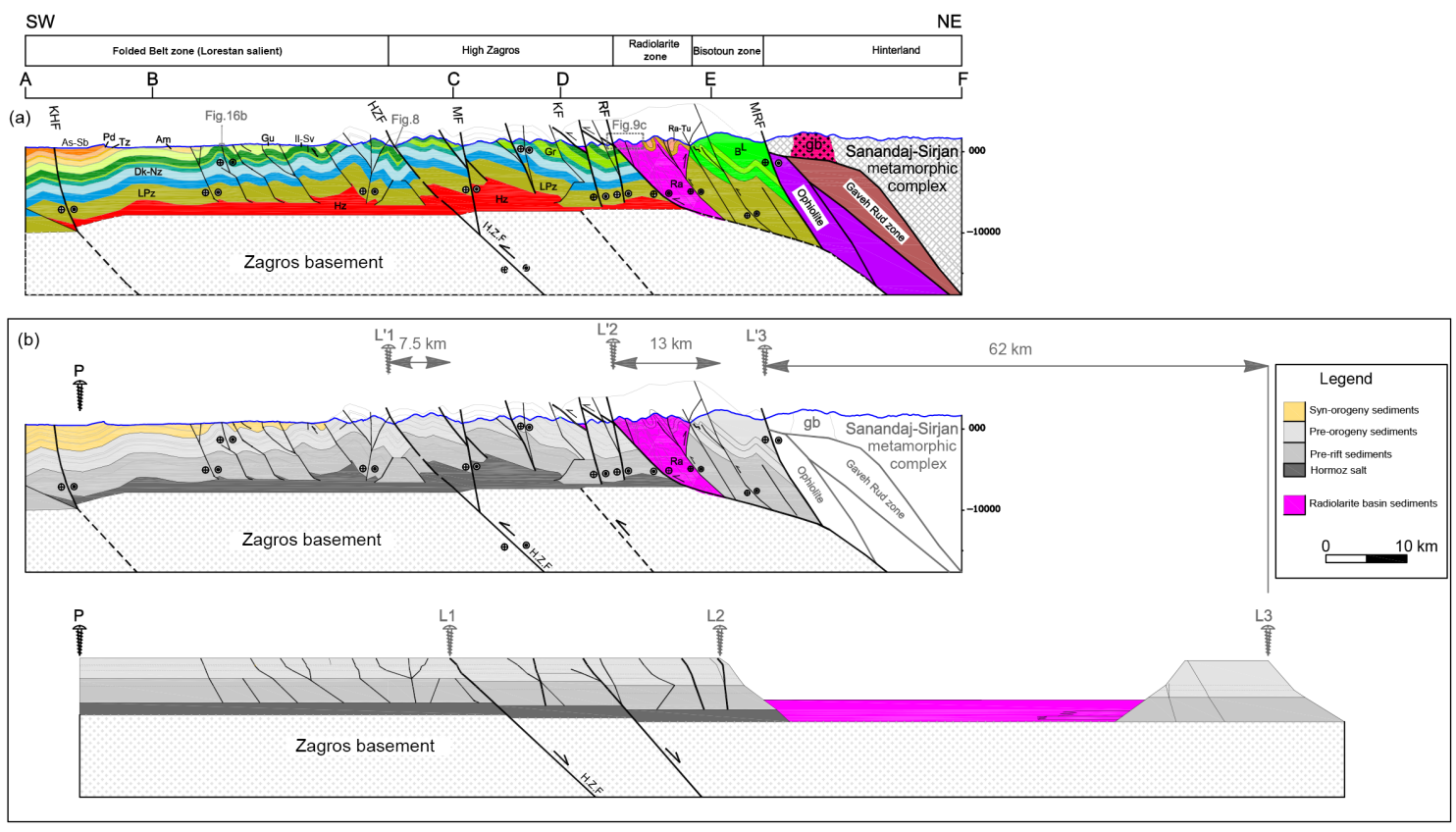

Figure 6. (a) Regional cross section across the Zagros orogeny in NW Iran (see line A-E in Fig. 2 for the section location and descriptions of its lithological and lithostratigraphic units); (b) restoration of the cross section. Abbreviations: HZF - High Zagros Fault; KF - Kermanshah Fault; MRF - Main Recent Fault; MF - Marekhil Fault; RF - Ravansar Fault; KHF - Khaneqin Fault.

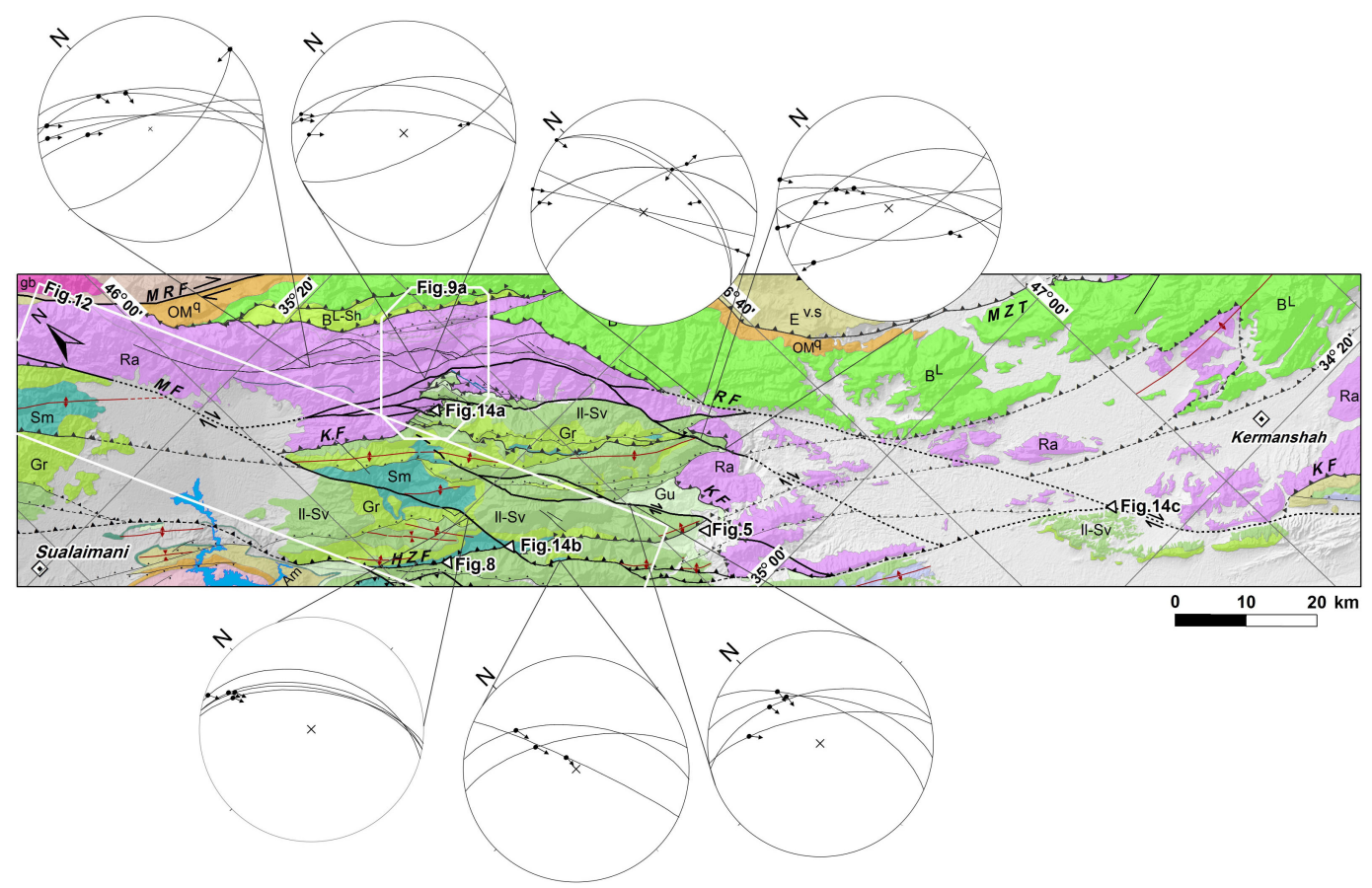

Figure 7. Structural map of the Kermanshah-Sulaimani (KS) area. Arrows in the lower hemisphere stereographic projections show the attitude of striae for movement direction of the late strike-slip fault of the late strike-slip faults. Abbreviations: MZT - Main Zagros Thrust; HZF - High Zagros Fault; KF - Kermanshah Fault; MRF - Main Recent Fault; MF - Marekhil Fault; RF - Ravansar Fault. 


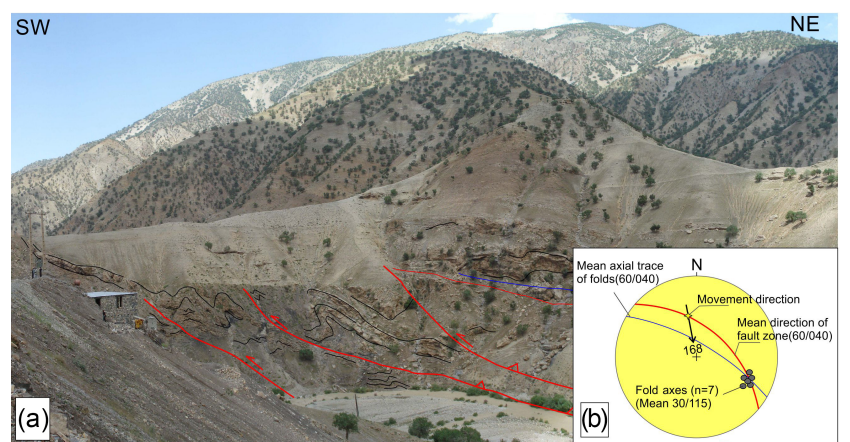

Figure 8. (a) Outcrop of the High Zagros Fault zone; (b) equal area lower hemisphere stereographic projection shows interpreted movement direction of High Zagros Fault zone (black arrow) using asymmetric folds' geometries developed within the fault zone (numbers show measured attitudes). For the location refer to Fig. 7.

2003) (Fig. 15). These structures are cut by a series of NNWtrending transverse dextral-slip faults (Figs. 15 and 16a) and ENE-trending sinistral-slip faults (Figs. 15 and 16b) or normal faults with sinistral-slip components (Figs. 15 and 16c).

\section{Discussion}

The obduction of the Neotethyan oceanic crust over the Bisotoun zone occurred in the Maastrichtian-Paleocene along the so-called Main Zagros Thrust (Takin, 1972; Berberian, 1995) (Fig. 17a). Continuous subduction of the oceanic crust resulted in formation of the Gaveh Rud volcanic arc and Sanandaj-Sirjan metamorphic zone (Fig. 17b). In the late Eocene to early Miocene (Allen and Armstrong, 2008; Agard et al., 2005, 2011; Mouthereau et al., 2012), the Zagros collision zone formed by sequential emplacement of the Gaveh Rud volcanic arc (Homke et al., 2010; Vergés et al., 2011; Ali et al., 2013) and Sanandaj-Sirjan metamorphic zone (Berberian, 1995; McQuarrie and van Hinsbergen, 2013) over the ophiolite zone (Fig. 17c). These major compressional events in the northeastern margin of the Arabian Platform can be classified into the Late Cretaceous oblique obduction related transpressional deformation and Cenozoic partitioning of oblique convergence, described in more detail in the following sections.

\subsection{Late Cretaceous oblique obduction related transpressional deformation}

The early structures mapped in the Bisotoun and Radiolarite zones (Figs. 9 and 12) are considered to be the result of the Neotethys oceanic crust obduction. This obduction occurred in the Late Cretaceous (Kazmin et al., 1986; Agard et al., 2005; Wrobel-Daveau et al., 2010; Vergés et al., 2011; Karim et al., 2011) but it is here considered to continue to the Maastrichtian-Paleocene (Fig. 17a). Reconstruction of the Neotethys using global plate motions constrains the $\mathrm{Za}-$ gros oblique convergence in the Late Cretaceous (Seton et al., 2012). About $49 \mathrm{~km}$ (79\%) of shortening as obtained by restoration of the regional balanced geological cross section (Fig. 6b) is proposed for the Late Cretaceous oblique obduction event. In the Radiolarite zone, the early stage structures partitioned between dextral strike-slip dominated and reverse dominated domains (Figs. 9 and 10) are indicative of the Late Cretaceous transpressional deformation related to the oblique obduction (Fig. 17a). In the Bisotoun and NE margin of the Radiolarite zones, the structures related to oblique obduction are demonstrated only by dextral-reverse faults (Fig. 9a).

\subsection{Cenozoic partitioning of oblique convergence}

The main stage of deformation in the Zagros orogeny occurred during the Cenozoic (e.g., Falcon, 1974; Berberian and King, 1981). It is proposed here that $13 \mathrm{~km}(16.5 \%)$ of shortening measured by restoration of the regional cross section (Fig. 6b) occurred in the Cenozoic. Despite the contrasting interpretations regarding the Cenozoic tectonics, it is widely accepted that the strike-slip component of the Zagros oblique convergence is accommodated by the belt-parallel strike-slip faults (Talebian and Jackson, 2002; McQuarrie et al., 2003; Fakhari et al., 2008; Axen et al., 2010). The Marekhil-Ravansar fault system (Figs. 2 and 7) in the study area is evidence for such strike-slip faulting. This fault system laterally cuts the early structures of the dextral strikeslip dominated and reverse dominated domains (Figs. 9b and 10). The presence of later strike-slip faulting in the Radiolarite and High Zagros zones implies that strike-slip faulting is not confined to the MRF but distributed in the outer parts of the Zagros orogeny (Fig. 17c and d). The existence of these later strike-slip faults is also documented by Gavillot et al. (2010) in the High Zagros zone farther to the southeast. The measured $32 \mathrm{~km}$ of strike-slip displacement along the MF (Fig. 13b) implies that, apart from the MRF, the Marekhil-Ravansar Fault system has also accommodated a large amount of the Cenozoic strike-slip movement.

About $50 \mathrm{~km}$ of the Cenozoic strike-slip displacement is proposed by Talebian and Jackson (2002) for the MRF. In the study area, however, up to $16 \mathrm{~km}$ of strike-slip displacement for the MRF is suggested (Copley and Jackson, 2006; Alipoor et al., 2012). We propose that in the study area much of the $50 \mathrm{~km}$ of the Cenozoic strike-slip displacement proposed by Talebian and Jackson (2002) has been accommodated by the Marekhil-Ravansar fault system (Figs. 2 and 6).

Towards the Folded Belt zone part of the study area (the Salas area), faults are generally thrusts laterally cut by strikeslip faults (Figs. 2 and 15). Like the major transverse strikeslip faults in other parts of the Zagros Folded Belt zone (e.g., the Kazerun Fault; Authemayou et al., 2006), these strikeslip faults are more likely basement-controlled (e.g., Berberian, 1995; Hessami et al., 2001; Bahroudi, 2003). 

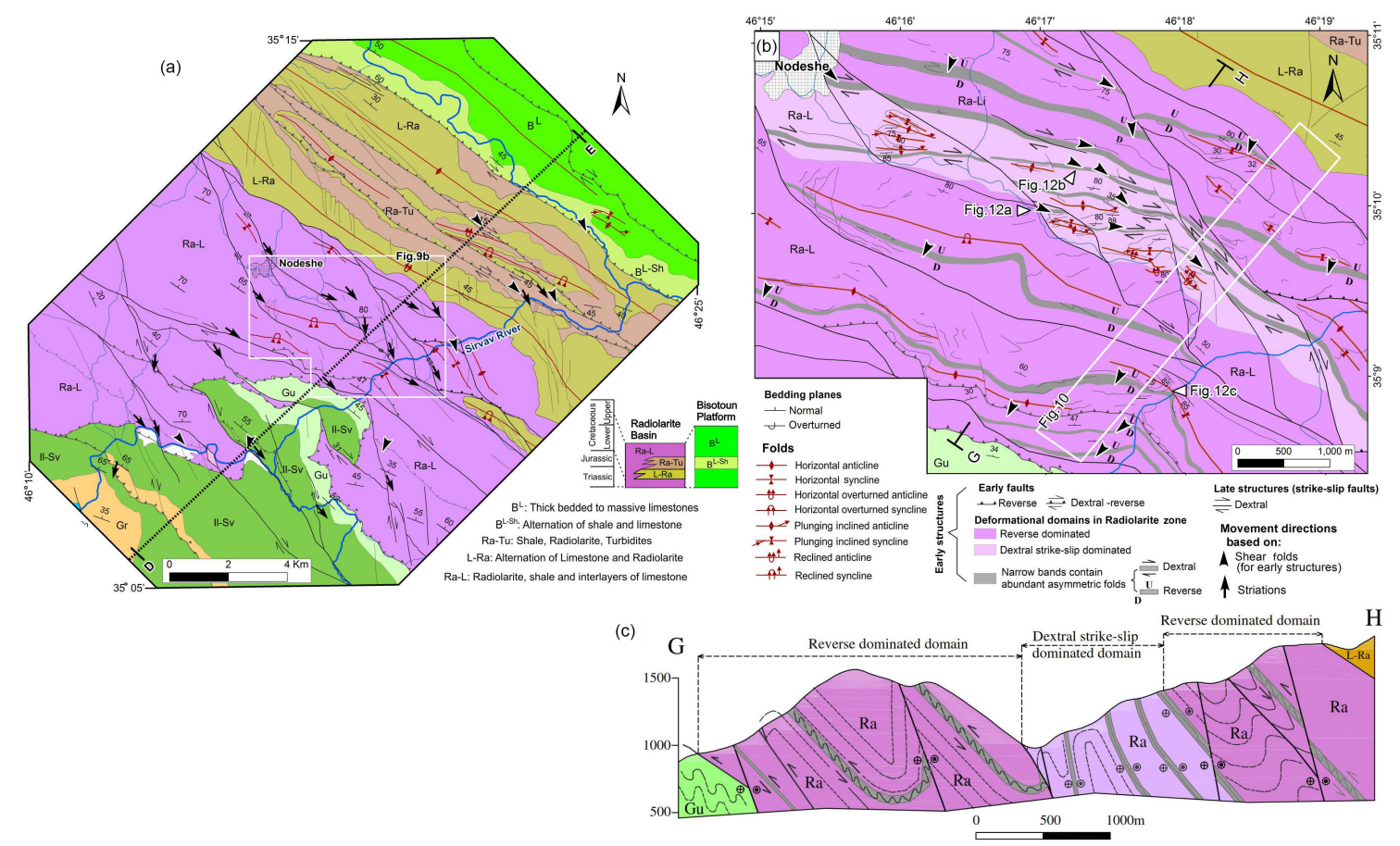

Figure 9. (a) Structural map of a part of the Kermanshah-Sulaimani (KS) area across the Bisotoun, Radiolarite and High Zagros zones. Arrows show movement direction of faults interpreted using asymmetric folds' striae. See Fig. 6 for the cross section between D and E; (b) simplified structural map of the early structures in the Radiolarite zone near the city of Nodeshe. Location of the figure within the KS area is shown by the white box. Note development of two domains: dextral strike-slip dominated domain, denoted by pink, and reverse dominated domain, denoted by violet; locations of Fig. 10 (by white box) and Fig. 12a, b, c (by white arrows) are shown on the map; (c) structural cross section along the line G-H, shown in Fig. 9b; the black lines are the late strike-slip faults.

\subsection{Constraints for Arabia-Eurasia oblique convergence}

There are two interpretations for initiation of the oblique convergence of the Arabia-Eurasia plates along the Zagros. In the first interpretation, Pliocene (3-5 Ma) initiation of the Zagros oblique convergence is suggested (e.g., Talebian and Jackson, 2002), whereas in the second interpretation oblique collision began in the early to middle Miocene (19-15 Ma; Gavillot et al., 2010) or earlier (Allen et al., 2004; Axen et al., 2010). The structural data presented in this paper are consistent with oblique convergence of the Arabia and Eurasia plates along the Zagros since the Late Cretaceous. We do not support a scenario for a change in the Arabia-Eurasia convergence from an orthogonal to an oblique direction (e.g., Navabpour and Barrier, 2012; Mouthereau et al., 2012). Thus, we propose that the Arabia-Eurasia oblique convergence along the Zagros occurred during all stages of the Zagros orogeny since the Late Cretaceous. Reconstructions of the Neotethys indicating oblique convergence of the Arabia and Eurasia plates since the Middle Jurassic (Seton et al., 2012) or Cretaceous (McQuarrie and van Hinsbergen, 2013) provide support for this proposal.

\section{Conclusions}

The main outcomes of this study are summarized as follows.

The presence of dextral strike-slip dominated and reverse dominated domains within the Radiolarite zone are indicative of oblique convergence during the Late Cretaceous obduction of the Neotethian oceanic realm onto the Arabian plate.

Zagros oblique convergence continued in the Cenozoic by southwestward propagation of the Zagros orogeny and resulted in development of thrust faults and related folds (in the Zagros Folded Belt zone) as well as overprinting of orogen-parallel strike-slip faults on the earlier Late Cretaceous obduction-related structures.

Restoration of the regional cross section across the Zagros collision zone demonstrated that a large amount of shortening (79\%) occurred during the Late Cretaceous obduction. Propagation of the Zagros orogeny toward its more external part (i.e., the Zagros Folded Belt zone) in the Late Tertiary resulted in $16.5 \%$ of shortening.

Cenozoic (early to middle Miocene) strike-slip faulting is not confined to the Zagros suture zone (i.e., the MRF), but it is distributed towards the more external parts of the orogen (i.e., along the Marekhil-Ravansar fault system). 

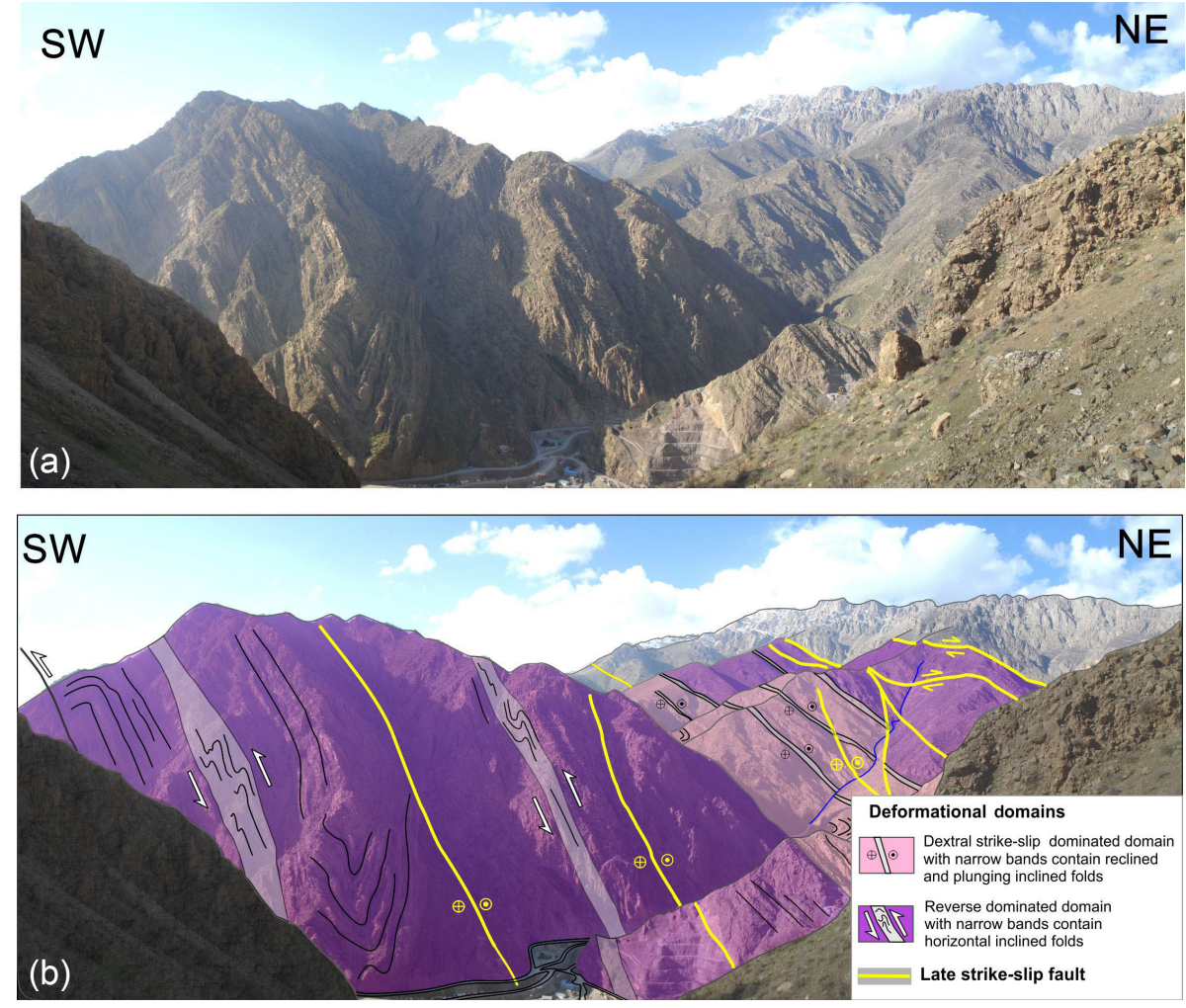

Figure 10. Field photo and line drawing of the Radiolarite zone near the city of Nodeshe (Fig. 9b). Note that the dextral strike-slip dominated domain (pinkish color area) is located within the reverse dominated domains.

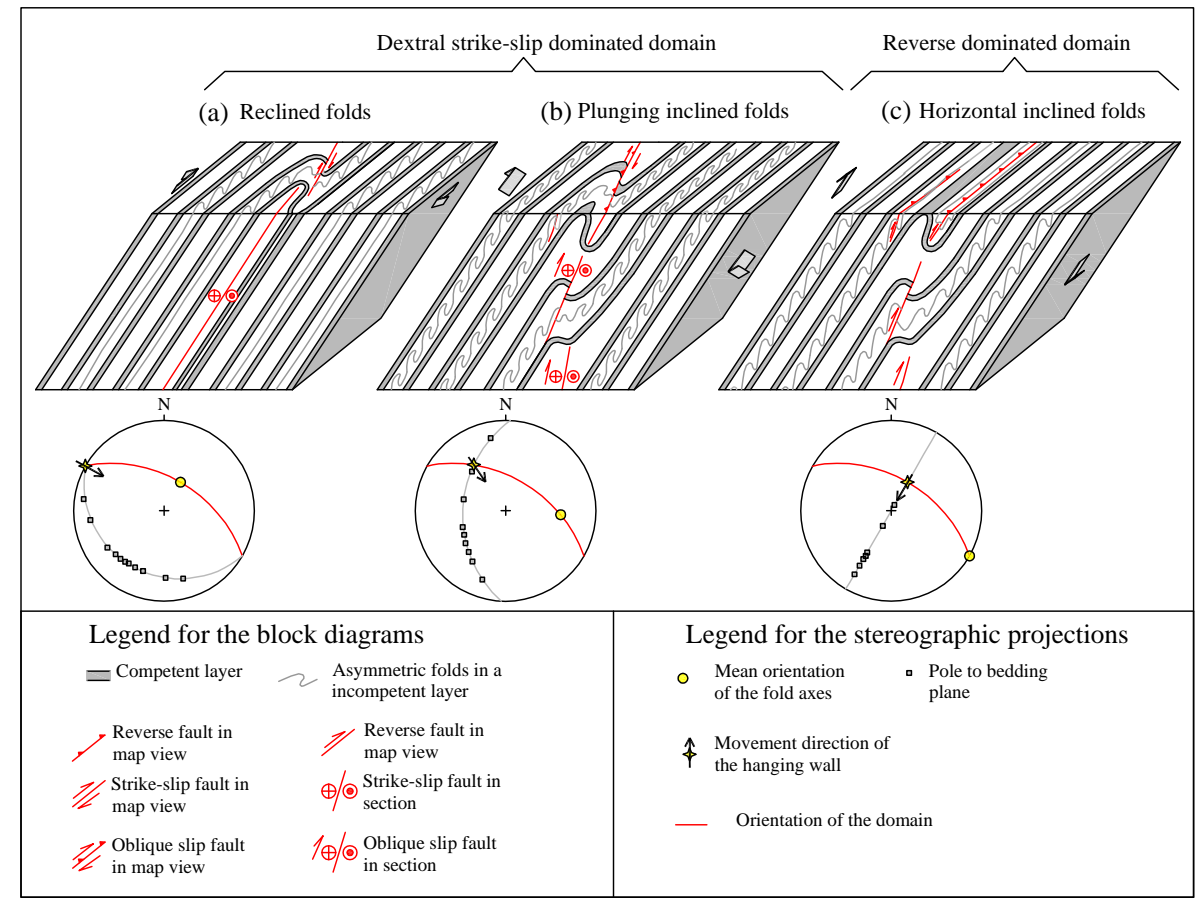

Figure 11. 3-D sketch diagrams adopted in this work on development of folds in two main types of deformational domains as dextral strike-slip and reverse dominated domains shown in Figs. 9b, 10 and 12. 

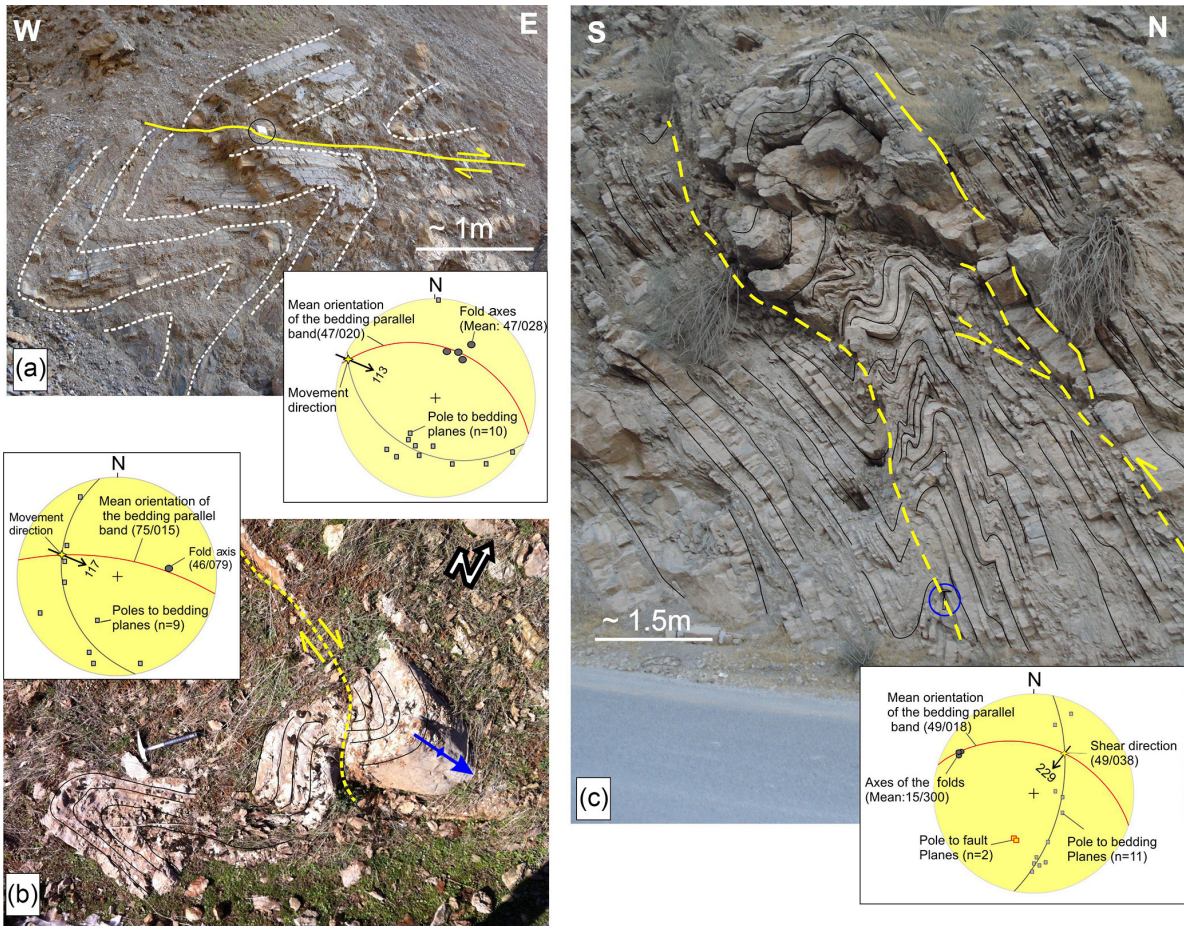

Figure 12. Bedding parallel bands in the Radiolarite zone and their kinematic interpretation using stereographic projection as (a) section view of bedding parallel bands with reclined folds, (b) plan view of bedding parallel band with plunging inclined folds and (c) bedding parallel bands with horizontal inclined folds. Equal area lower hemisphere stereographic projections show interpreted movement direction (black arrow) for the domains using asymmetric folds' geometries. For the locations refer to Fig. 9b.
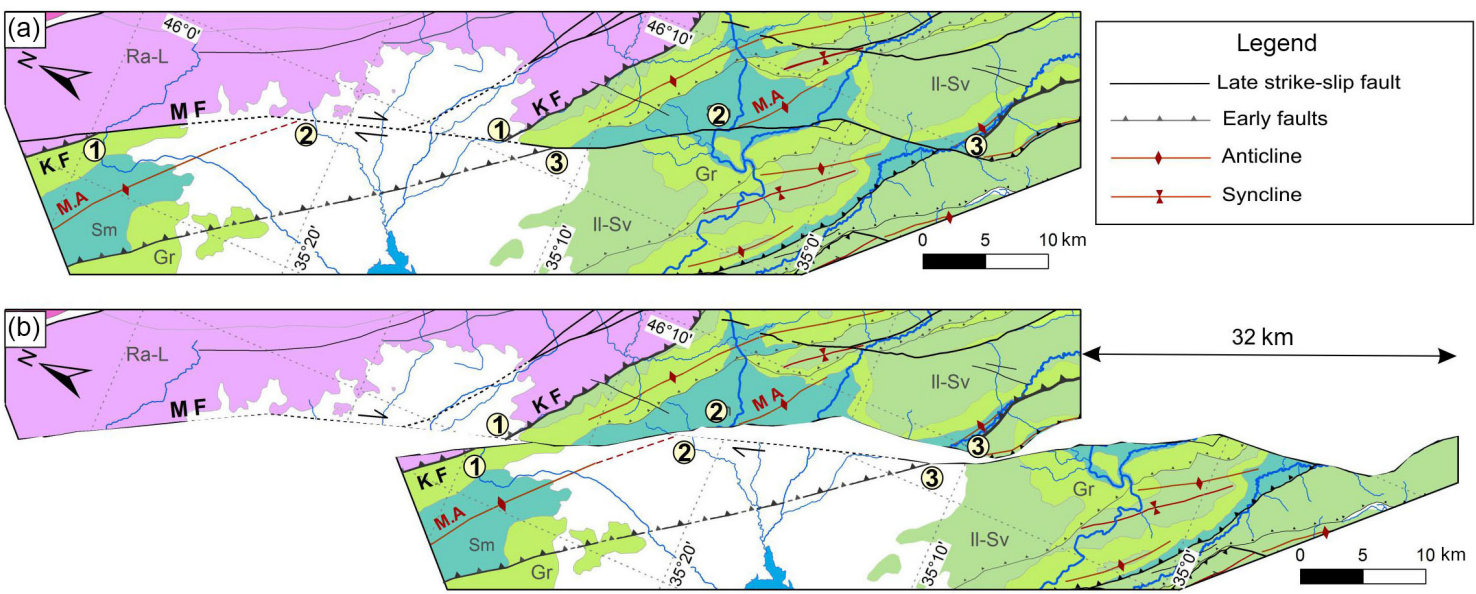

Figure 13. Restoration of about $32 \mathrm{~km}$ dextrally offset on the early structures by the Marekhil Fault (MF). The numbers in circles show locations of the older structures such as the Kermanshah Fault (KF), Marekhil Anticline (MA) and a thrust fault on both walls of the Marekhil Fault; (a) before restoration; (b) after restoration. 

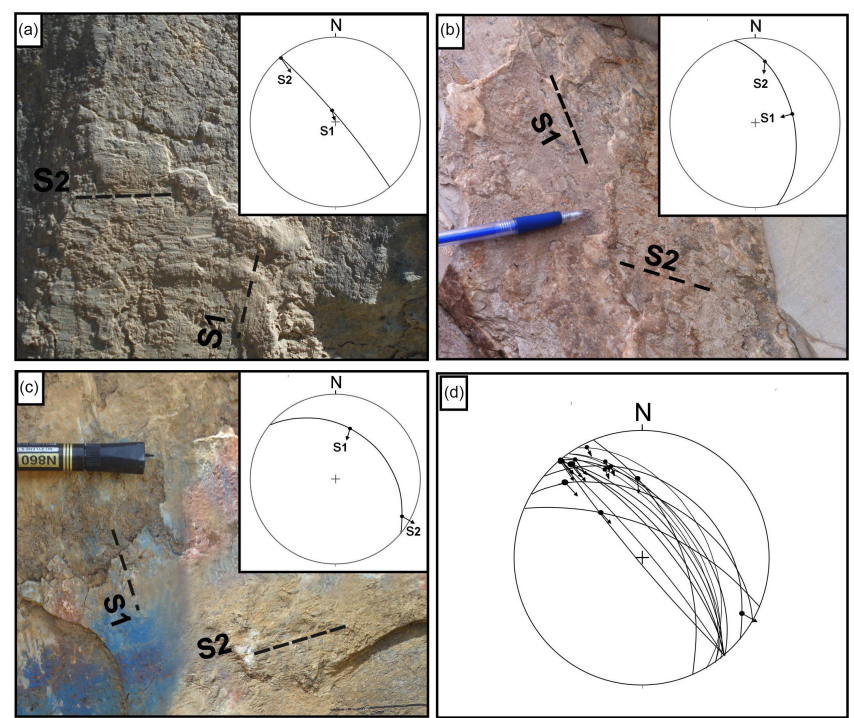

Figure 14. (a, b, c) Fault planes with two generations of striae. First generation (S1) is reverse-slip but second generation (S2) has oblique to dextral strike-slip kinematics. For the photographs' locations refer to Figs. 2 and 7; (d) lower hemisphere equal area stereographic projection showing cumulative late faults in the $\mathrm{KS}$ area.

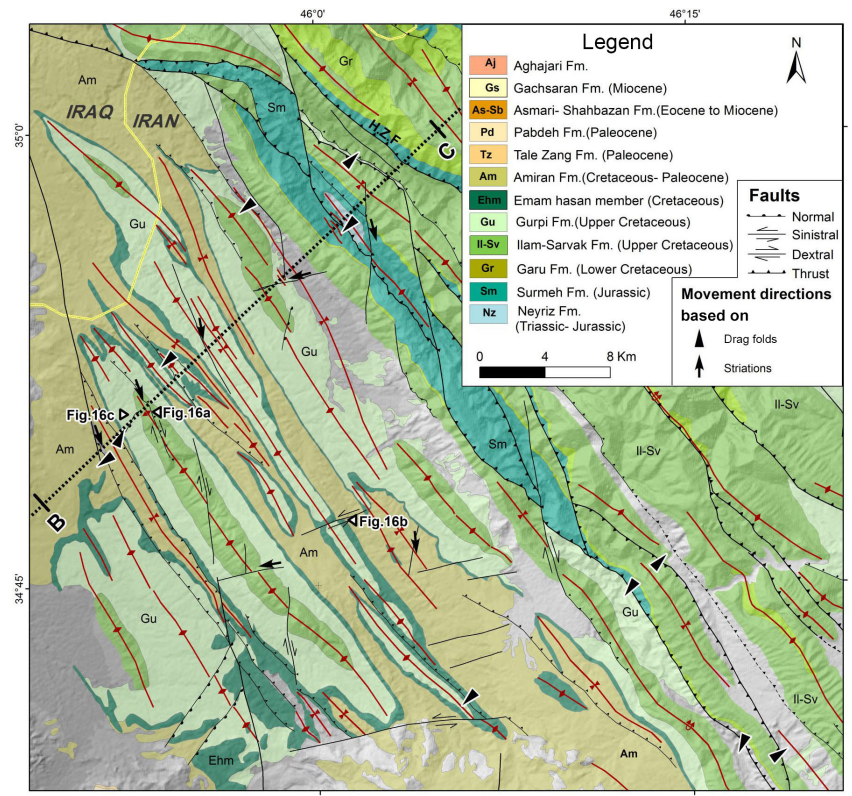

Figure 15. Structural map of the Salas area. For the location of the map area refer to Fig. 3. The cross section line that goes through points $\mathrm{B}$ and $\mathrm{C}$ is presented in Fig. 6.

Distribution of the dextral transpressional deformation in the Kurdistan area of the Zagros indicates that oblique convergence of the Arabia-Eurasia plates guided the entire history of the Zagros orogeny (since the Late Cretaceous).
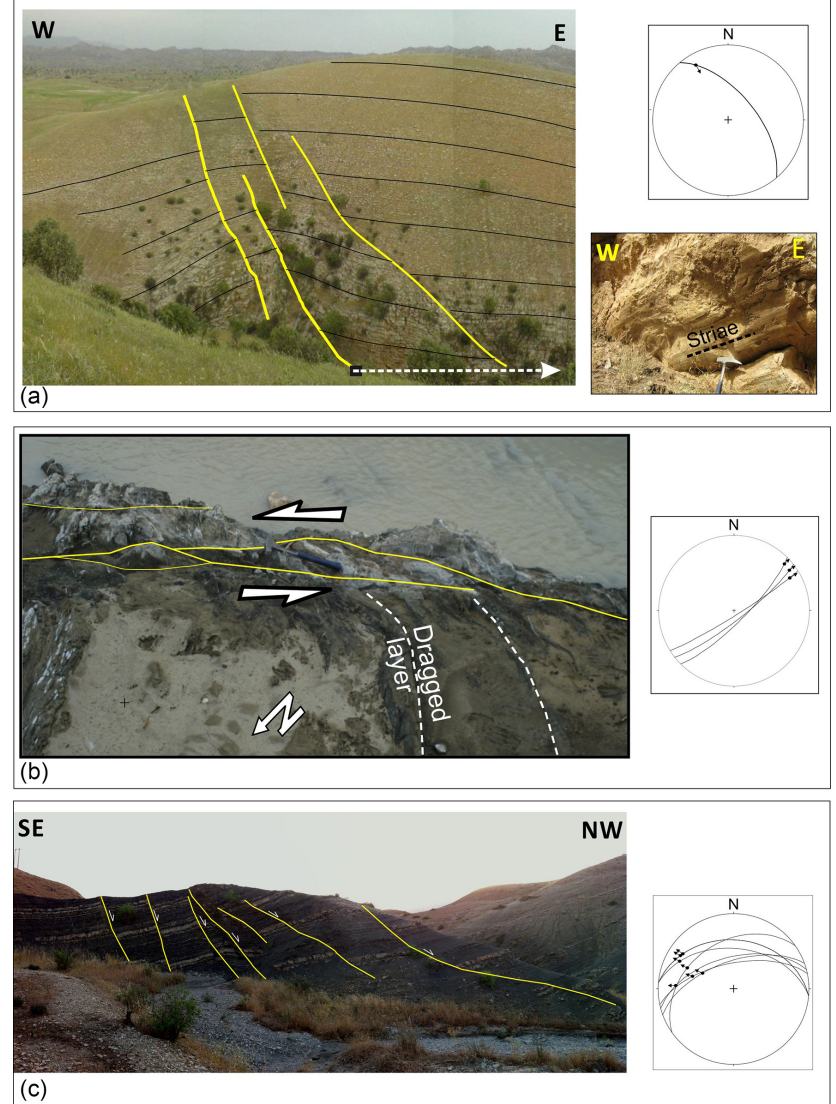

Figure 16. Photographs of fault zones in the Salas area: (a) dextralslip fault (b) sinistral-slip fault and nearby dragged layers; (c) normal faults with sinistral components. For the locations, refer to Fig. 15.

Acknowledgements. The people of the Kurdistan province of Iran are acknowledged for their support during fieldwork in the high Zagros Mountains near the Iran and Iraq border. Note that this area is very difficult to access due to remaining mine fields from 8 years of war. The authors thank C. L. Fergusson, F. Rossetti and P. B. Ballato for their constructive reviews and valuable comments and suggestions that improved the revised version of this paper.

Edited by: F. Rossetti

\section{References}

Agard, P., Omrani, J., Jolivet, L., and Mouthereau, F.: Convergence history across Zagros (Iran): constraints from collisional and earlier deformation, Int. J. Earth Sci., 94, 401-419, 2005.

Agard, P., Omrani, J., Jolivet, L., Whitechurch, H., Vrielynck, B., Spakman, W., Monié, P., Meyer, B., and Wortel, R.: Zagros orogeny: a subduction-dominated process, in: Geodynamic Evolution of the Zagros, edited by: Lacombe, O., Grasemann, B., and Simpson, G., Geological Magazine, Cambridge, UK, 692-725, 2011. 
(a) Mastrichtian-Paleocene, closure of the Radiolarite basin - Partitioning of oblique convergence in Radiolarite zone

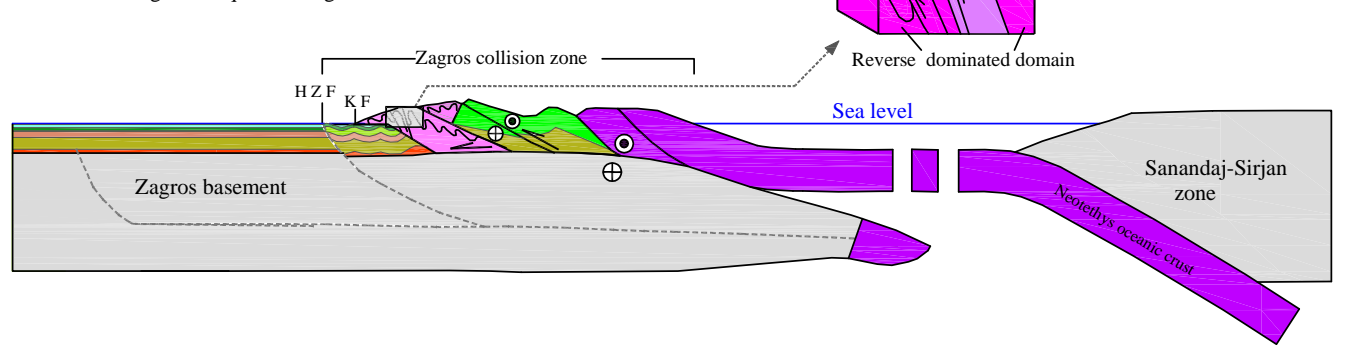

(b) Late Paleocene, evolving the Gaveh Rud zone

No major compressive event in the Zagros collision zone

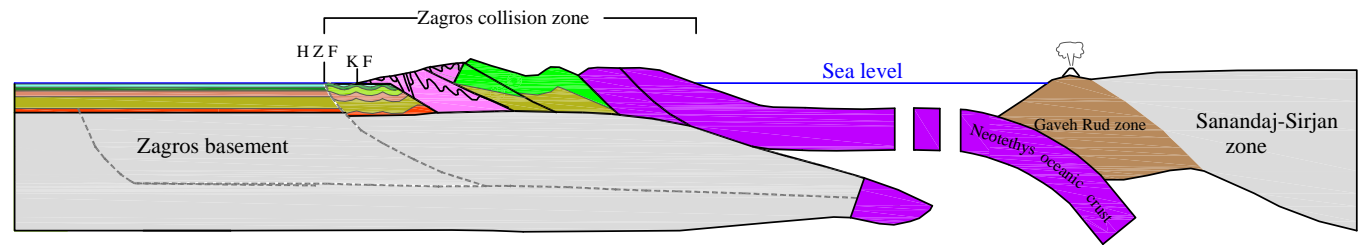

(c) Early to middle Miocene, collision with the Sanandaj-Sirjan zone

- Partitioning of convergence to late strike-slip faults in collision zone and propagation of simply fold belt normal to belt - Involvement of the Zagros basement in compressional deformation.

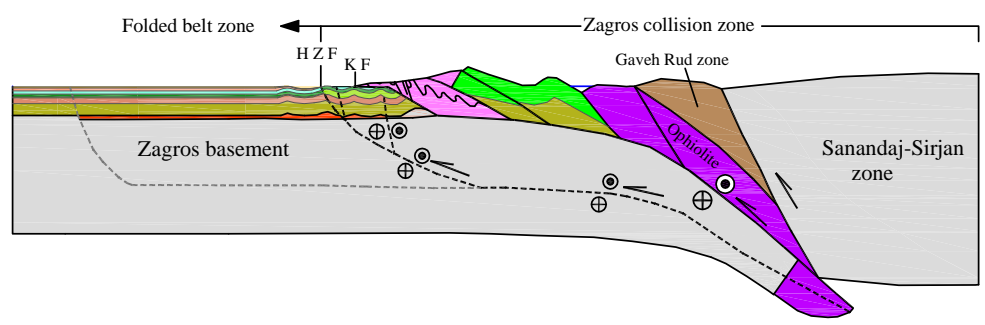

(d) Late Miocene-Pliocene, reaching the folded belt zone to the mountain front

(d) - Continuous strike-slip faulting in the Zagros collision zone,

- Reaching the deformation front to the Khanaqin fault.

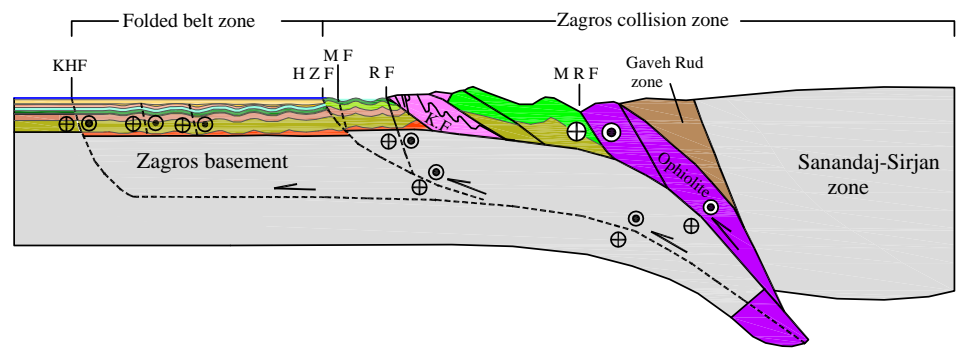

Figure 17. Conceptual model showing different deformation stages for the Zagros oblique convergence since the Late Cretaceous. (a) The obduction resulted in development of the early structures (inset shows the partitioning of oblique convergence into the two dextral strike-slip dominated and reverse dominated domains); (b) The Gaveh Rud zone as the forearc of the Sanandaj-Sirjan zone; (c) evolvement of the Zagros collision zone by emplacement of the Gaveh Rud and Sanandaj-Sirjan zones over the Bisotoun and Radiolarite zones, as well as initiation of the late regional strike-slip faults; (d) propagation of the deformation front toward the Zagros foreland. Not to scale; location of structures is only indicative. Modified and readapted after Agard et al. (2005, 2011), Vergés et al. (2011) and Farahpour and Hessami (2012). 
Alavi, M.: Regional Stratigraphy of the Zagros fold-thrust belt of Iran and its proforeland evolution, Am. J. Sci., 304, 1-20, doi:10.2475/ajs.304.1.1, 2004.

Ali, S., Mohajjel, M., Aswad, K., Ismail, S., Buckman, S., and Jones, B.: Tectono-stratigraphy and general structure of the northwestern Zagros collision zone across the Iraq-Iran border, J. Environ. Earth Sci., 4, 92-110, 2013.

Alipoor, R., Zaré, M., and Ghassemi, M. R.: Inception of activity and slip rate on the main recent fault of Zagros Mountains, Iran, Geomorphology, 175-176, 86-97, 2012.

Allen, M. B. and Armstrong, H. A.: Arabia-Eurasia collision and the forcing of mid-Cenozoic global cooling, Palaeogeogr. Palaeocl., 265, 52-58, 2008.

Allen, M., Jackson, J., and Walker, R.: Late Cenozoic reorganization of the Arabia-Eurasia collision and the comparison of shortterm and long-term deformation rates, Tectonics, 23, TC2008, doi:10.1029/2003TC001530, 2004.

Authemayou, C., Chardon, D., Bellier, O., Malekzadeh, Z., Shabanian, E., and Abbassi, M. R.: Late Cenozoic partitioning of oblique plate convergence in the Zagros fold-and-thrust belt (Iran), Tectonics, 25, TC3002, doi:10.1029/2005TC001860, 2006.

Axen, G., Fakhari, M., Guest, B., Gavillot, Y., Stockli, D. F., and Horton, B.: Distributed Oblique-dextral Transpression in the High Zagros Mountains, Iran, in: Tectonic Crossroads: Evolving Orogens of Eurasia-Africa-Arabia, Ankara, Turkey, Abstracts, 73 pp., 2010.

Azizi, H. and Jahangiri, A.: Cretaceous subduction-related volcanism in the northern Sanandaj-Sirjan Zone, Iran, J. Geodyn., 45, 178-190, 2008.

Bahroudi, A.: The Effect of Mechanical Characteristics of Basal Décollement and Basement Structures on Deformation of the Zagros Basin, PhD Thesis, Uppsala University, Uppsala, Sweden, 43 pp., 2003.

Bahroudi, A. and Koyi, H. A.: E_ect of spatial distribution of Hormuz salt on deformation style in the Zagros fold and thrust belt: an analogue modelling approach, J. Geol. Soc. London, 160, 115, 2003.

Berberian, M.: Master "blind" thrust faults hidden under the Zagros folds; active basement tectonic and surface morphotectonics, Tectonophysics, 241, 193-224, 1995.

Berberian, M. and King, G. C. P.: Towards a paleogeography and tectonic evolution of Iran, Can. J. Earth Sci., 18, 210-265, 1981.

Beydoun, Z. R.: Arabian Plate Hydrocarbon, Geology and Potential - A plate Tectonic Ap- proach, American Association of Petroleum Geology, Studies In Geology, 33, 77 pp., 1991.

Braud, J.: La suture du Zagros au niveau de Kermanshah (Kurdistan Iranien): reconstitution paléogéographique, évolution géodynamique, magmatique et structurale, PhD Thesis, ParisSud, Orsay, p. 488, 1987

Casciello, E., Vergés, J., Saura, E., Casini, G., Fernandez, N., Blanc, E., Homke, S., and Hunt, D. W.: Fold patterns and multilayer rheology of the Lurestan Province, Zagros Simply Folded Belt (Iran), J. Geol. Soc. London, 166, 947-959, doi:10.1144/001676492008-138, 2009.

Colman-Sadd, S.: Fold development in Zagros simply folded belt, Southwest Iran, AAPG Bull., 62, 984-1003, 1978.
Copley, A. and Jackson, J.: Active tectonics of the Turkish-Iranian Plateau, Tectonics, 25, TC6006, doi:10.1029/2005TC001906, 2006.

Doblas, M.: Slickenside kinematic indicators, Tectonophysics, 295, 187-197, 1998.

Fakhari, M. D., Axen, G. J., Horton, B. K., Hassanzadeh, J., and Amini, A.: Revised age of proximal deposits in the Zagros foreland basin and implications for Cenozoic evolution of the High Zagros, Tectonophysics, 451, 170-185, 2008.

Falcon, N. L.: Southern Iran: Zagros Mountains, in: MesozoicCenozoic Orogenic Belts, edited by: Spencer, A., Geological Society, London, Special Publications, London, UK, 4, 199-211, 1974.

Farahpour, M. and Hessami, K.: Cretaceous sequence of deformation in the SE Zagros fold -thrust belt, J Geol. Soc. London, 169 733-743, doi:10.1144/jgs2012-042, 2012.

Farzipour-Saein, A., Yassaghi, A., Sherkati, S., and Koyi, H.: Mechanical stratigraphy and folding style of the Lurestan region in the Zagros Fold-Thrust Belt, Iran, J. Geol. Soc. London, 166, 1101-1115, doi:10.1144/0016-76492008-162, 2009.

Fleuty, M. J.: The description of folds, in: Proceedings of the Geologist's Association, 75, London, UK, 461-492, 1964.

Fontaine, J. M., Monod, O., Braud, J., and Perincek, D.: The Hezan Units: a fragment of south Neo-Theethyan passive continental margin in SE Turkey, J. Petrol. Geol., 12, 29-50, 1989.

Gavillot, Y., Axen, G. J., Stockli, D. F., Horton, B. K., and Fakhari, M. D.: Timing of thrust activity in the High Zagros fold-thrust belt, Iran, from (U/Th)/He thermochronometry, Tectonics, 29, TC4025, doi:10.1029/2009TC002484, 2010.

Gharib, F. and De Wever, P.: Mesozoic radiolarians from the Kermanshah formation (Iran), C. R. Palevol., 9, 209-219, 2010.

Gidon, M., Berthier, F., Billiautt, J.-P., Halbronn, B., and Maurizot, P.: Sur quelques caractères de la tectonique Néocrétacée dans la région de Borudjerd (Zagros Oriental, Iran), Comptes Rendus de l'Académie des Sciences, 278, 577-580, 1974.

Harrison, P. M., Frost, S. H., Seiglie, G. A., and Scheneidermann, N.: Regional unconformities and depositional cycles, cretaceous of the Arabian Peninsula, AAPG Memoir., 36, 67-80, 1984.

Hatzfeld, D. and Molnar, P.: Comparisons of the kinematics and deep structures of the Zagros and Himalaya and of the Iranian and Tibetan plateaus and geodynamic implications, Rev. Geophys., 48, RG2005, doi:10.1029/2009RG000304, 2010.

Hessami, K. Koyi, H. A., Talbot, C. J., Tabasi, H., and Habanian, E. S.: Progressive unconformities within an evolving foreland foldand-thrust belt, Zagros Mountains, J. Geol. Soc. London, 158, 969-981, 2001.

Homke, S., Vergés, J., Van Der Beek, P., Fernàndez, M., Saura, E., Barbero, L., Badics, B., and Labrin, E.: Insights in the exhumation history of the NW Zagrosfrom bedrock and detrital apatite fission-track analysis: evidence for a long-lived orogeny, Basin Res., 22, 659-680, 2010.

James, G. A. and Wynd, J. G.: Stratigraphic nomenclature of Iranian oil consortium agreement area, AAPG Bull., 49, 2162-2245, 1965.

Jassim, S. Z. and Buday, T.: Tectonostratigraphy of the Zagros suture, in: Geology of Iraq, edited by: Jassim, S. Z. and Go, C., Dolin, Prague and Moravian Museum, Brno, Czech Republic, 341 pp., 2006. 
Jones, R. R., Holdsworth, R. E., Clegg, P., McCarey, K., and Tavarnelli, E.: Inclined transpression, J. Struct. Geol., 26, 1531-1584, 2004.

Karim, K. H., Koyi, H., Baziany, M. M., and Hessami, K.: Significance of angular unconformities between Cretaceous and Tertiary strata in the northwestern segment of the Zagros fold-thrust belt, Kurdistan Region, NE Iraq, Geol. Mag., 148, 925-939, 2011.

Kazmin, V. G., Ricou, L. F., and Sbortshikov, I. M.: Structure and evolution of the passive margin of the eastern Tethys, Tectonophysics, 123, 153-179, 1986.

Koop, W. J. and Stoneley, R.: Subsidence history of the Middle East Zagros Basin, permian to recent, Philos. T. Roy. Soc. A, 305, 149-168, 1982.

McClusky, S., Balassanian, S., Barka , A., Demir, C., Ergintav, S., Georgiev, I., Gurkan, O., Hamburger, M., Hurst, K., Kahle, H., Kastens, K., Kekelidze, G., King, R., Kotzev, V., Lenk, O., Mahmoud, S., Mishin, A., Nadariya, M., Ouzoums, A., Paradissis, Y. P., Prilepin, M., Reilinger, R., Sanli, I., Seeger, H., Tealeb, A., Toksoz, M. N., and Veis, G.: Global Positioning System constraints on plate kinematics and dynamics in the eastern Mediterranean and Caucasus, J. Geophys. Res., 105, 5695-5719, 2000.

McQuarrie, N.: Crustal scale geometry of the Zagros fold-thrust belt, Iran, J. Struct. Geol., 26, 519-535, 2004.

McQuarrie, N. and van Hinsbergen, D. J. J.: Retrodeforming the Arabia-Eurasia collision zone: Age of collision versus magnitude of continental subduction, Geology, 41, 315-318, 2013.

McQuarrie, N., Stock, J. M., Verdel, C., and Wernicke, B. P.: Cenozoic evolution of neotethys and implications for the causes of plate motions, Geophys. Res. Lett., 30, 2036, doi:10.1029/2003GL017992, 2003.

Mohajjel, M. and Fergusson, C. L.: Dextral transpression in Late Cretaceous continental collision, Sanandaj-Sirjan Zone, western Iran, J. Struct. Geol., 22, 1125-1139, 2000.

Mohajjel, M., Fergusson, C. L., and Sahandi, M. R.: CretaceousTertiary convergence and continental collision, Sanandaj-Sirjan Zone, western Iran, J. Asian Earth Sci., 21, 397-412, 2003.

Molinaro, M., Leturmy, P., Guezou, J.-C., and Frizon de Lamotte, D.: The structure and kinematics of the south-eastern Zagros fold-thrust belt; Iran: from thin-skinned to thick-skinned tectonics, Tectonics, 24, TC3007, doi:10.1029/2004TC001633, 2005.

Motiei, H.: Stratigraphy of Zagros, Treaties on the Geology of Iran, Geol. Survey of Iran Publication, Tehran, Iran, 536 pp., 1993 (in Persian).

Mouthereau, F., Tensi, J., Bellahsen, N., Lacombe, O., De Boisgrollier, T., and Kargar, S.: Tertiary sequence of deformation in a thin-skinned/thick-skinned collision belt: the Zagros Folded Belt (Fars, Iran), Tectonics, 26, TC5006, doi:10.1029/2007TC002098, 2007.

Mouthereau, F., Lacombe, O., and Vergés, J.: Building the Zagros collisional orogen: timing, strain distribution and the dynamics of Arabia/Eurasia plate convergence, Tectonophysics, 532-535, 27-60, 2012.

Navabpour, P. and Barrier, E.: Stress states in the Zagros fold-andthrust belt from passive margin to collisional tectonic setting, Tectonophysics, 581, 76-83, doi:10.1016/j.tecto.2012.01.011, 2012.
Nemati, M. and Yassaghi, A.: Structural characteristics of the transitional zone from internal to external parts of the Zagros orogen, Iran, J. Asian Earth Sci., 39, 161-172, 2010.

Ricou, L. E., Braud, J., and Brunn, J. H.: Le Zagros, Société Géologique de France, Mémoire Hors Série, 8, 33-52, 1977.

Sarkarinejad, K.: Quantitative finite strain and kinematic flow analyses along the Zagros transpression zone, Iran, Tectonophysics, 442, 49-65, 2007.

Sarkarinejad, K. and Azizi, A.: Slip partitioning and inclined dextral transpression along the Zagros Thrust System, Iran, J. Struct. Geol., 30, 116-136, 2008.

Searle, M. P. and Graham, G. M.: "Oman Exotics" - oceanic carbonate build-ups associated with the early stages of continental rifting, Geology, 10, 43-49, 1982.

Seton, M., Müller, R. D., Zahirovic, S., Gaina, C., Torsvik, T., Shephard, G., Talsma, A., Gurnis, M., Turner, M., Maus, S., and Chandler, M.: Global continental and ocean basin reconstructions since 200 Ma, Earth-Sci. Rev., 113, 212-270, 2012.

Sherkati, S. and Letouzey, J.: Variation of structural style and basin evolution in the central Zagros (Izeh zone and Dezful Embayment), Iran, Mar. Pet. Geol., 21, 535-554, 2004.

Sherkati, S., Letouzey, J., and Frizon de Lamotte, D.: Central Zagros fold-thrust belt (Iran): new insights from seismic data, field observation, and sandbox modeling, Tectonics, 25, TC4007, doi:10.1029/2004TC001766, 2006.

Stocklin, J.: Structural history and tectonics of Iran; a review, AAPG Bull., 52, 1229-1258, 1968.

Takin, M.: Iranian geology and continental drift in Middle East, Nature, 235, 147-150, 1972.

Talbot, C. J. and Alavi, M.: The past of a future syntaxisacross the Zagros, in: Salt Tectonics, edited by: Alsop, G. I., Blundell, D. J., and Davison, I., Geological Society of London, London, UK, Special Publication no. 100, 89-109, 1996.

Talebian, M. and Jackson, J.: Offset on the main recent fault of NW Iran and implicationson the late Cenozoic tectonics of the Arabia-Eurasia collision zone, Geophys. J. Int., 150, 422-439, 2002.

Vergés, J., Saura, E., Casciello, E., Fernàndez, M., Villaseñor, A., Jiménez-Munt, I., and GarcíaCastellanos, D.: Crustal-scale cross-section across the NW Zagros Belt: implications for the Arabian Margin reconstruction, in: Geodynamic Evolution of the Zagros, edited by: Lacombe, O., Grasemann, B., and Simpson, G., Geological Magazine, Cambridge, UK, 148, 739-761, 2011.

Vernant, P., Nilforoushan, F., Hatzfeld, D., Abassi, M., Vigny, C., Masson, F., Nankali, H., Martinod, J., Ashtiani, A., Bayer, R., Tavakoli, F., and Chery, J.: Contemporary crustal deformation and plate kinematics in Middle East contrained by GPS measurements in Iran and northern Oman, Geophys. J. Int., 157, 381-398, 2004.

Wrobel-Daveau, J.-C., Ringenbach, J.-C., Tavakoli, S., Ruiz, G. M. H., Masse, P., and Frizon De Lamotte, D.: Evidence for mantle exhumation along the Arabian margin in the Zagros (Kermanshah area, Iran), Arabian Journal of Geosciences, 3, 499-513, 2010. 